Note: Supplementary information is available on the Nature Methods website.

71. Salwinski, L. et al. Recurated protein interaction datasets. Nat. Methods 6, 860-861 (2009).

72. Lee, I., Li, Z. \& Marcotte, E.M. An improved, bias-reduced probabilistic functional gene network of baker's yeast, Saccharomyces cerevisiae. PLoS ONE 2, e988 (2007).

73. Wu, J. et al. Integrated network analysis platform for protein-protein interactions. Nat. Methods 6, 75-77 (2009).
74. Hart, G.T., Ramani, A.K. \& Marcotte, E.M. How complete are current yeast and human protein-interaction networks? Genome Biol. 7, 120 (2006).

75. Chatr-aryamontri, A. et al. MINT and IntAct contribute to the Second BioCreative challenge: serving the text-mining community with high quality molecular interaction data. Genome Biol. 9, S5 (2008).

76. Blow, N. Systems biology: untangling the protein web. Nature 460, 415-418 (2009).

77. Geisler-Lee, J. et al. A predicted interactome for Arabidopsis. Plant Physiol. 145, 317-329 (2007).

\title{
Corrigendum: Nanoscale live-cell imaging using hopping probe ion conductance microscopy
}

Pavel Novak, Chao Li, Andrew I Shevchuk, Ruben Stepanyan, Matthew Caldwell, Simon Hughes, Trevor G Smart, Julia Gorelik, Victor P Ostanin, Max J Lab, Guy W J Moss, Gregory I Frolenkov, David Klenerman \& Yuri E Korchev Nat. Methods 6, 279-281 (2009); published online 1 March, 2009; corrected after print 3 September 2009.

In the version of this paper originally published, references to previous work on pulse mode SICM should have been included (Mann, S.A. et al. J. Neurosci. Methods 116, 113-117, (2002) and Happel, P. et al. J. Microsc. 212, 144-151 (2003)). These references were removed during shortening of the paper for publication and have been added back to the PDF and HTML versions of this article. The pulse mode technique reported in these previous papers has conceptual similarity to our hopping mode SICM, in that distance feedback control is not continuous; thus, it also solves the problem of probe-sample collision for large cellular structures. However, the pulse mode technique is considerably slower owing to a different feedback mechanism and does not perform at nanoscale resolution.

\section{Erratum: 'Edgetic' perturbation of a C. elegans BCL2 ortholog}

Matija Dreze, Benoit Charloteaux, Stuart Milstein, Pierre-Olivier Vidalain, Muhammed A Yildirim, Quan Zhong, Nenad Svrzikapa, Viviana Romero, Géraldine Laloux, Robert Brasseur, Jean Vandenhaute, Mike Boxem, Michael E Cusick, David E Hill \& Marc Vidal Nat. Methods 6, 843-849 (2009); published online 25 October, 2009; corrected after print 16 November 2009.

In the version of this article initially published, the schematic in Figure $5 \mathrm{a}$ was misaligned. The error has been corrected in the HTML and PDF versions of the article.

\section{Erratum: What's in a test?}

\author{
Anonymous \\ Nat. Methods 6, 783 (2009); published online 29 October 2009; corrected after print 16 November 2009
}

In the version of this article initially published, the name of Robert Cook-Deegan was misspelled. The error has been corrected in the HTML and PDF versions of the article. 